\title{
Financial Management Practices and Growth of Small and Medium-Scale Enterprises: The case of Kassena-Nankana West District
}

\author{
Godfrey Adda (Corresponding Author) \\ Bolgatanga Polytechnic \\ P.O. Box 767, Bolgatanga \\ Upper East Region, Ghana \\ Tel: 233-54-918-4657 \\ E-mail: godfreyadda@bpoly.edu.gh
}

$\begin{array}{lrr}\text { Received: February 2, } 2020 & \text { Accepted: March 31, } 2020 \quad \text { Published: April 14, } 2020 \\ \text { doi:10.5296/rbm.v7i2.16844 } & \text { URL: http://dx.doi.org/10.5296/rbm.v7i2.16844 }\end{array}$

\begin{abstract}
The promotion of financial management practices and growth of Small and Medium-scale Enterprises (SMEs) can contribute significantly towards the sustained elevation of a nation for a better or more humane life. SMEs play a crucial role in addressing the impediments of poverty, inequality and job creation. Yet, many SMEs face numerous challenges ranging from the lack of capital, poor management skills and the application of best financial management practices.

This paper explores SMEs' financial management skills and practices in relation to their growth. The study used questionnaire to collect data from managers or owners of SMEs. Descriptive statistics was used to present the results of the data. Not only that but also, a multiple regression model was also used to test the correlation between financial management practices of SMEs and business growth. The results indicate a moderate correlation between the financial management practices of the SMEs and the growth of the enterprises. Based on the findings, it is recommended for targeted financial education programmes to help managers and owners of SMEs develop and adopt best financial management practices.
\end{abstract}

Keywords: Small and medium enterprises, financial management practices, enterprise growth, Kassena-Nankana West District, Ghana

\section{Introduction}

The Kassena-Nankana West District is one of the thirteen districts in the Upper East Region of Ghana. Agriculture which is the dominant economic activity in the local economy of the district employs over $68.7 \%$ of the people (GSS, 2014). However, due to the erratic rainfal partern, 
there is no major farming activity half of the year (October to April) when the rains stop (CIDA, 1999). Consequently, poverty is substantial in the district. The incidence of poverty in the district is estimated at $70 \%$ (GSS, 2014).

Thus, the promotion of small and medium-scale enterprises (SMEs) can address the impediments of poverty, inequality and job creation (Gebregizabher \& Akeem, 2015). An increase in SMEs' growth can transform rural populations into higher household income earners (Maksimov, Wang \& Luo, 2017). SMEs are easy to start, requires comparably less capital, and they can produce goods and services for both local demand and export (Mahanti, 2019).

Although more than $85 \%$ of enterprises in Ghana are SMEs, majority of them are not competitive and in most instances fail to survive or grow (International Trade Centre, 2016). The major challenges to the development of the SME sector include shortage of debt and equity financing, high cost of borrowing and rigid interest rates (Abor \& Quartey, 2010). Not only that but also, inadequate financial management skills and application of best financial management practices are some of the factors contributing to SMEs' failure (Akande, 2011; Adeniran \& Johnston, 2012).

In this regard, the aim of the study is to contribute to the advancement in the relevant literature towards effective financial management practices and growth of SMEs. This knowledge could be important for existing and future managers of SMEs as well as business school educators and entrepreneurship as a whole. In next to follow, a review of the literature is presented to put the study in perspective, followed by the methods through which data were collected to illuminate the research topic. In the concluding part, the findings are discussed, then recommendations and conclusion made.

\section{Literature Review}

\subsection{Entrepreneurship and SMEs}

Entrepreneurship and SMEs' development has globally been acknowledged as a vehicle for economic growth and development (Churchill, 2013). Entrepreneurship and SMEs are concepts that tend to be used interchangeably to describe businesses with limited resources seeking to achieve the same goal or objective, but despite the similarities of these concepts, there are also differences (Lee-Ross \& Lashley, 2009). Entrepreneurship differs from SMEs to the extent that entrepreneurship is a process leading to the creation of SMEs and business ventures; whereas SMEs only represents firms or businesses in small and medium sizes.

The literature on entrepreneurship is characterized by a proliferation of theories, definitions and taxonomies that often conflict and overlap (Lee-Ross \& Lashley, 2009; Parker, 2003). As a result, there is no unanimity as to who the word 'entrepreneur' should be applied to (Richtermeyer, 2002). However, in almost all of the theories and definitions of entrepreneurship, there is agreement as to the kind of behaviour that it entails (Hisrich, Peters $\&$ Shepherd, 2005). This behaviour includes: 1) taking of initiative; 2) the organisation of social and economic mechanisms to turn resources and situations into practical accounts; 3) the acceptance of risk or failure, and; 4) the rewards of independence, personal satisfaction, profit, 
money or success (Hisrich, Peters \& Shepherd, 2005).

Kuratko and Hodgetts (2004) define entrepreneurship as a dynamic process of vision, change and creation which requires the application of energy and passion for implementing new ideas and creative solutions: the essential ingredients of which are 1) the willingness to take calculated risks in terms of time, equity, or career; 2) the ability to formulate an effective venture team; 3) the creative skill to marshal needed resources; and 4) the vision to recognize opportunity where others see chaos, contradiction, and confusion. Further, entrepreneurship is the driving force for initiating business ideas, mobilizing human, financial and physical resources for establishing and expanding enterprises, and job creation (ILO, 2004).

Similar to entrepreneurship, there is no universally accepted definition of SMEs, as different countries have different criteria for defining SMEs (Berisha \& Pula, 2015; European Commission, 2005). Whereas SMEs are referred to as small businesses, others describe them differently (small and medium sized enterprises, small and medium enterprises, or micro, small and medium enterprises). Generally, SMEs are defined mainly using criteria such as: number of employees, sales volume and value of assets (Longenecker \& Loeza, 2010; OECD, 2017). In this context, SMEs are defined as economic enterprises or activities which employ not more than one hundred persons, and whose total asset base (excluding land and buildings) does not exceed the cedi equivalent of $\$ 1$ million in value (Venture Capital Trust Fund, 2004); and are businesses financed by one individual or a group of individuals who are geographically localised (OECD, 1997).

The role of SMEs as the engine of economic growth has long been established (Aryeetey \& Ahene, 2005; ILO, 2007). Across countries, SMEs have an important role to play in achieving the Sustainable Development Goals (SDGs) by promoting inclusive and sustainable economic growth, providing decent employment, and reducing income inequalities (OECD, 2017). Their role in terms of production, employment generation, contribution to exports and equitable distribution of income is very critical. The sector can provide opportunities to a large number of capable and potential entrepreneurs who are deprived of appropriate opportunities (OECD, 2017).

SMEs make up more than $95 \%$ of all businesses worldwide, and represent a path to poverty eradication in developing countries (Abor \& Quartery, 2010; Kauffmann, 2006). In Ghana, the SME sector is made up of business activities such as provisions and retailing shops, supermarkets, restaurants, food vendors, hair dressing, barbering salons, clothing and tailoring shops, carpentry and furniture shops, and small scale manufacturers of fruit drinks, and sachet water (Ackah \& Vuvor, 2011). Those in rural areas comprise mostly family businesses, women in production of local crops, leather works, timber and mining (Kayanula \& Quartey, 2000). Other value-added SME activities in the agriculture value chain include; meat and fish processing, rice milling, groundnut oil and shea butter extraction. Pottery, blacksmithing, artisanry and traditional weaving of textiles are also undertaken in some communities in small scale (JICA, 1999).

SMEs are the backbone of the Ghanaian economy representing about $85 \%$ of businesses, largely within the private sector, and contributing about $70 \%$ of Ghana's gross domestic 
product (GDP) (International Trade Centre (ITC), 2016). Additionally, the SME sector is estimated to be made up of $70 \%$ of all industrial establishments, and absorb more than $60 \%$ of the employed labour force in rural areas (GLSS-3, 2002). If properly structured and capitalized, SMEs have the potential to grow and spearhead the accelerated growth of the economy and rural areas (GPRSII, 2005).

Despite the important role SMEs play in the Ghanaian economy, the financial constraints they face are daunting, leading to a negative impact on their development and potential for driving the economy (Abor \& Quartery, 2010). Financial access is critical for the growth of SMEs as it allows entrepreneurs to innovate, improve efficiency, and also expand their businesses (World Bank, 2016). Therefore, there is the need to improve the business conditions of SMEs, especially access to/and the management of financial resources for sustainability.

\subsection{SMEs and Financial Accessibility}

In both developing and developed economies, easy access to credit is a very important factor in accelerating investments and for transforming small businesses into strong enterprises (OECD, 2017). However, in many African countries, access to credit is mainly the reserve of corporate bodies, leaving out small enterprises whose micro-investments can have a great bearing on the economy (Faye \& Thouraya, 2013). SMEs face greater financing obstacles than larger firms as they enjoy less access to external finance and face higher transactions costs and higher risk premiums (World Bank Group, 2018). For example, around 25\% of SMEs in Africa are classified as credit constrained (World Bank Group, 2018).

Africa's financial system is under development in terms of low income levels, inflation, high illiteracy rates, inadequate infrastructure, governance challenges, high cost of borrowing and rigid interest rates (Faye \& Thouraya, 2013; Mensah, 2004). The sector tends to suffer because SMEs are viewed as a less attractive investment opportunity due to the high levels of uncertainty and risk factors including a limited track record in raising investment and suitable returns to investors, non-existent or very limited internal controls, and few tangible assets to offer as security (ILO, 2007). This calls for inclusivity of the financial infrastructure and services for sustainable enterprises.

The importance of financial inclusion is increasingly recognized by policymakers around the world (Blancher, 2019; World Bank Group, 2018). According Blancher (2019), financial inclusion refers to making financial products and services accessible and affordable to all individuals and businesses, regardless of their personal net-worth or company size; and that it strives to remove the barriers that exclude people from participating in the financial sector. Improving SME financial inclusion can help increase economic growth, job creation, and the effectiveness of fiscal, monetary policy and financial stability (Blancher, 2019).

\subsection{SMEs and Sources of Financing}

Business financing involves the procurement and utilization of funds for effective and efficient business operations (Arcand, Berkes \& Panizza, 2015). Across all stages of their life cycle, SMEs require access to appropriate sources of financing for their creation, survival and growth (Abbasi, Wang \& Abbasi, 2017; OECD, 2018). SMEs need finance for a variety of purposes 
including providing working capital, hiring staff and re-financing of existing loans. Without finance, SMEs cannot acquire or absorb new technologies and expand to compete in global markets or strike business linkages with larger firms (United Nations, 2001).

Financial services cover a range of products or instruments, including credit, savings, insurance, leases, equity investments, payment services and remittances (International Labour Organization, 2007). Commercial banks, non-governmental organizations (NGOs), and credit unions have traditionally provided the bulk of credit to SMEs (Beck, 2013). In Ghana, various governments have attempted to operate lending schemes for SMEs (Mensah, 2004). For example, the Business Assistance Fund was established in the 1990s to provide direct lending to the SME sector. Not only that but also, the Ghana Investment Fund was established in 2002 as a credit facility by financial institutions to augment the capacities of various companies. Additionally, the Export Development and Investment Fund (EDIF) was established to aid export oriented companies borrow up to $\$ 500,000$ over a five-year period at a subsidized cedi interest rate of $15 \%$.

Debt and equity are the two major sources of financing for SMEs and entrepreneurs (Abbasi, Wang, \& Abbasi, 2017; OECD, 2015). Equity financing means exchanging a portion of the ownership of the business for a financial investment in the business. Equity financing comes from many sources including an entrepreneur's friends and family, or other investors (Abbasi et al., 2017). Through private equity, wealthy individuals, investment funds or institutions participate fully in the entrepreneurial risk of the business as capital is made available without the provision of security.

On the other hand, debt financing involves borrowing funds from creditors with the stipulation of repaying the borrowed funds plus interest at a specified future time (OECD, 2015). Debt financing occurs when a firm raises money for working capital or capital expenditures by selling debt instruments to individuals and/or institutional investors (Abbasi et al., 2017). In return, the individuals or SMEs receive a promise that the principal and interest will be repaid. Debt finance is the most widely used form of finance as it is generally one of the least expensive ways to raise funds (Quartey, Abor, \& Iddrisu, 2017).

SMEs can also be funded internally and externally (Abbasi et al., 2017). Whereas internal funds include investment profits, sales of assets, extended payment terms, reduction in working capital and accounts receivable; external sources are from firm owners and relatives, banks, financial institutions, suppliers, merchants, government and non-government organizations (Beck, 2013). Bank lending is the most common source of external finance for many SMEs and entrepreneurs (OECD, 2018). However, in Ghana, bank loans account for less than onequarter of SMEs' total debt financing (Abor \& Biekpe, 2007).

\subsection{Constraints to SMEs Financing}

In Ghana, the lack of adequate access to credit is the leading factor stifling the growth of small businesses (AGI, 2011). Small firms have limited access to capital and money markets, and therefore suffer from chronic undercapitalization (Nkuah, Tanyeh \& Gaeten, 2013). SMEs are regarded by investors as high-risk borrowers due to insufficient assets and low capitalization, vulnerability to market fluctuations and high mortality rates (United Nations, 2001). Banks 
regard SMEs as too risky and expensive to give loans to (Hishigsuren, Spahr, Estevez \& Magnoni, 2014).

Typical barriers to accessing bank finance for SMEs include the lack of collateral, brief or nonexistent business track records, cost of finance, fragile financial and management systems, and the uncertainty of profitability (Shinozaki, 2012). Lending to SMEs is mostly based on collateral than is the case for larger firms (Blazy \& Weill, 2013). Collateral is an asset pledged by a borrower to a lender for a loan for the purposes of redemption in case of a default (Balkenhol \& Schütte, 2001). However, the collateral available to SMEs is often inadequate for projects due to the fact that the backed collaterals are usually lowly rated by lending banks to ensure that the loan is realistically covered in case of default (Binks et al., 1992). Moreover, in developing countries, $78 \%$ of SME collaterals are in the form of movable assets (i.e., machinery, equipment, or receivables), but inadequate legal and regulatory environments in these countries make banks reluctant to accept movable assets as collateral (Alvarez, 2011).

In addition, the availability of relevant data is critical for the assessment of SME financing needs by financial institutions (Alliance for Financial Inclusion, 2019). Appropriate data enable the differentiation and segmentation of SMEs for suitable interventions to specific groups. Accurate and comprehensive data also inform the selection, prioritization, sequencing, benchmarking and monitoring of SME finance (Demirguc-Kunt, Beck \& Honohan, 2008). Unfortunately, assessing the creditworthiness of SMEs is a challenge as a result of the lack of credit information of most SMEs (Ayyagari, Demirgüç-Kunt \& Maksimovi, 2017). Also, SMEs often do not have audited financial statements that allow a better picture of the enterprise and its projected profits (Nkuah et al., 2013). Moreover, such small firms also lack proper accounting procedures and owners easily mix their business and personal finances, making their financial statements unreliable (Abor \& Quartey, 2010).

The cost of finance is another major constraint to SMEs in developing countries (Abor, 2007). Lending to small businesses can be seen to be time consuming and costly for banks and other financial intermediaries. Furthermore, high transaction costs of processing, monitoring, and enforcing small loans increase breakeven interest rates for loans (Ayyagari et al., 2017). Also, access to competitive interest rates is reserved for blue-chip companies while loan interest rates offered to SMEs remain high (United Nations, 2001). Moreover, high administrative and transaction costs of lending or investing small amounts do not make SME financing a profitable business.

Traditionally, most banks in many developing countries lend to governments because it is considered less risky and can also offer higher returns. This is detrimental to private sector borrowers including SMEs (OECD, 2018). A way to reduce financing obstacles for SMEs is to strengthen the infrastructure that supports financial transactions, not forgetting the laws, regulations and institutions to create, register and enforce collateral, insolvency regimes and credit reporting tools (Blancher, 2019). A good business environment enables entrepreneurs provide the incentives for enterprises to thrive (International Labour Organization, 2007). Thus, irrespective of the accessability to financial services, entrepreneurs will be discouraged from taking reasonable risks if the business environment is volatile, precarious or constraining. Therefore, lending institutions should endeavour to improve their ability to provide financial 


\section{Macrothink $\Lambda$ Institute ${ }^{\mathrm{m}}$}

services to SMEs through commercial mechanisms that reduce costs and yet, minimize their risk exposure (United Nations, 2001).

Also, the management of SMEs is an acknowledged challenge that has proved difficult to overcome (OECD, 2000). SME owners are often managers of their enterprises and usually have no formal qualifications in management and leadership (De Kok, Uhlaner \& Thurik, 2006). Banks, before they provide loans, often assess one's personal qualities and competence to run a firm and the capability to manage funds. Studies show that there is a positive relationship between higher education, management experience and skills as well as business planning and business growth. Particularly, SME skills and strategic vision are key ingredients in any effort to broaden the range of financing instruments (OECD, 2018).

\subsection{SMEs and Financial Management Skills and Practices}

Financial management entails the planning, organizing, directing and controlling of financial activities such as the procurement and utilization of funds of enterprises (Ross, Westerfield \& Jaffe, 2009). The financial management functions of a business include investment decisions, financial decisions and dividend decisions (Marx, De Swardt, Beaumont-Smith, Naicker \& Erasmus, 2004). While investment decisions relate to investment in fixed assets or capital budgeting; financial decisions relate to raising finance from various sources; dividend decisions relate to profits and the proportion that should be retained in a business to finance development and growth, including the proportion which may be distributed to the owners.

Unfortunately, SMEs' participation in the business sector is challenged by factors including entrepreneur incapacity, inadequate financial skills, and poor management practices (Akande, 2011; Adomako \& Danso, 2014; Nkosi, Bounds \& Goldman, 2013; Anokye, 2017; Ansong \& Gyensare, 2012). For example, the misuse of capital, poor cost control and poor cash flow management are serious challenges of many entrepreneurs (Cornwall, 2005). If SMEs are not managed well from a financial management point of view, they cannot survive over the medium to long term (Agyei-Mensah, 2011; Anokye, 2017; Ansong \& Gyensare, 2012; Nunoo \& Andoh, 2012). A study by Rajaram and O'Neill (2009) in KwaZulu-Natal found that most SMEs did not possess the financial management skills needed to function optimally and to reach their full potential with regard to profitability and growth.

Other studies (Mensah, Azinga \& Sodji, 2015; Mbroh \&Attom, 2011; Musah, Gakpetor \& Pomaa, 2018; Prempeh, 2015) in Ghana revealed that most owners and managers of SMEs had limited formal education and weak management skills, and that these deficiencies inhibit the growth and sustainability of their businesses. For example, a study by Afrifa (2013) on the impact of education and work experience on SME financial management concluded that managers who had more education and experience were better placed for financial management. Also, Nketsiah (2015) noted in a study that $80 \%$ of SMEs had poor financing management capabilities and as such use manual records as opposed to computerized records for record keeping. Similarly, Mbroh and Attom (2011) in a study also concluded that most SMEs fail to keep proper books of accounts due to low levels of education and inadequate knowledge in accounting procedures. 


\section{Macrothink Minstitute}

The financial literacy levels of owners/managers of SMEs are important in explaining the utilization of financial services (Nunoo \& Andoh, 2012). The financial capability of SME managers or owners can affect their behaviour in managing business finances (O'Donnell \& Keeney, 2010; Finlayson, 2009). Standard financial management practices can give SMEs an accurate depiction of business finances including revenues, expenses, profits, capital, cash flow and formal records that provide in-depth insights into financial information (International Finance Corporation, 2017). Record keeping, determining future profitability, managing working capital, measuring past performance, tax and legal entity compliance are identified as key aspects where small business owners require training (Kirsten, 2013).

Schwarze (2008) recommends that in order to survive, SMEs should first acquire financial management skills that assist in short-term decision making. In a similar fashion, Gitman (2010) identifies two components of short-term planning for small businesses such as profit planning and cash flow planning. Profit planning involves forecasting income and expenditure while cash flow planning involves forecasting cash flows. Thus, there is no gainsaying that targeted financial education programmes can help entrepreneurs develop and improve their long-term strategic approaches to business financing, enhance the understanding of the economic and financial landscape of relevance to their business, identify and approach providers of finance and investors, understand and manage risks for different financial instruments (Kirsten, 2013).

\section{Research Methodology}

The study adopted a quantitative approach involving the use questionnaire for data collection (i.e., Cohen, Manion \& Morrison, 2007). The use of this approach to research allowed for a straightforward analysis of the data. The stage sampling technique was used to select the SMEs $(\mathrm{N}=120)$ composed of merchants, government contractors, petty traders, sachet water producers and other service providers. Thereafter, questionnaires were administered to the owners/managers of the SMEs. One aspect of the questionnaires covered dichotomous variables relating to respondent sex, educational status, and type of enterprise. The other aspect was on SME age, financial management skills and enterprise performance was on a scale of 15: Where; (1) Strongly Disagree, (2) Disagree, (3) Neither Agree nor Disagree, (4) Strongly Agree, and (5) Strongly Agree). The returned questionnaire were $(\mathrm{N}=110)$ representing a retrieval rate of $73 \%$. The Cronbach's Alpha coefficient test of the resulting data was $(0.5: \alpha=$ 0.903 ) which is satisfactory (Kline, 2011).

Dependent variable: The dependent variable is the age of the SME. The number of years an enterprise has been in operation affects its ability to grow (Mann \& Sager 2007). Also, the age of a business is associated with the firm's risk of failure, success or performance. Age could actually help firms become more efficient (Martins, Ligthelm \& Wijk, 2003).

Independent variables: These variables concern SME managers'/owners' educational status, work experience, and their financial management practices.

\subsection{Multiple Regression Model}

A multiple regression model was used to test the correlation between SME financial practices 
and enterprise growth. A multiple regression model was preferred because it reveals statistical relationships between variables and can be used to predict or estimate the behaviour of variables (Kline, 2011). The model summarizes the relationship between the dependent variable $\mathrm{Y}$ and multiple independent variables $\mathrm{X}$.

$$
\begin{aligned}
& \mathrm{Y}=\beta 0+\beta 1 \mathrm{X} 1+\beta 2 \mathrm{X} 2+\beta 3 \mathrm{X} 3+\beta 4 \mathrm{X} 4+\mathrm{e} \\
& \text { Where: } \mathrm{Y}=\text { Enterprise Performance } \\
& \beta \mathrm{o}=\text { Constant } \\
& \mathrm{B} 1-\mathrm{B} 4=\text { Beta coefficients } \\
& \mathrm{X} 1=\text { Educational status of managers/owners } \\
& \mathrm{X} 2=\text { Entrepreneur experience } \\
& \mathrm{X} 3=\text { Audited financial statement } \\
& \mathrm{X} 4=\text { Keeps track of expenditure and income } \\
& \mathrm{e}=\text { Error term }
\end{aligned}
$$

\section{Results}

The first part of the results presents a frequency tabulation of SME owner/manager sex, educational status, and type of enterprise. Followed by a descriptive analysis (means and standard deviation) of the data on SME owner/manager financial management practices. Thereafter, a multiple regression which test the relationship between SME financial practices and business growth was used.

\subsection{Respondent Demographics}

Table 1. Sex of respondents

\begin{tabular}{lllll}
\hline & Frequency & Percent & Valid Percent & Cumulative Percent \\
\hline Male & 65 & 54.1 & 59.1 & 59.1 \\
Female & 45 & 37.5 & 40.9 & 100.0 \\
Total & 110 & 91.6 & 100.0 & \\
No response & 10 & 8.4 & & \\
Total & 120 & 100.0 & & \\
\hline
\end{tabular}

Source: Field work, 2019

Table 2. Nature and type of SME enterprises

\begin{tabular}{lllll}
\hline & Frequency & Percent & Valid Percent & Cumulative Percent \\
\hline Manufacturing (water sachet) & 4 & 3.3 & 3.6 & 3.6 \\
\hline
\end{tabular}




\begin{tabular}{lllll}
\hline Services & 37 & 30.8 & 33.6 & 37.3 \\
Petty trade & 61 & 50.8 & 55.5 & 92.7 \\
Merchants/Construction & 8 & 6.6 & 7.3 & 100.0 \\
Total & 110 & 91.6 & 100.0 & \\
No response & 10 & 8.3 & & \\
Total & 120 & 100.0 & & \\
\hline
\end{tabular}

Source: Field work, 2019

Table 1 below (see appendix 1) presents a frequency tabulation of the sex of owners/managers of the SMEs. As can be observed from the table, a total $(\mathrm{N}=65)$ or $54 \%$ are male, and $(\mathrm{N}=$ 45) are female.

Table 2 below (see appendix 1) presents a frequency tabulation of the nature or type of businesses of the SMEs. As can be observed from the table, a majority are engaged in petty trading and services such hospitality businesses, internet cafes and other communication business ventures representing $(\mathrm{N}=37)$ or $31 \%$ and $(\mathrm{N}=61)$ or $51 \%$ respectively. Only $(\mathrm{N}=$ $4)$ or $3 \%$ and $(\mathrm{N}=8)$ or $7 \%$ are into the manufacturing and merchant sectors.

Table 3. SME managers' educational status

\begin{tabular}{lllll}
\hline & Frequency & Percent & Valid Percent & Cumulative Percent \\
\hline Not at all & 30 & 25.3 & 27.3 & 27.3 \\
Basic & 47 & 39.1 & 42.7 & 70.0 \\
Secondary & 23 & 19.1 & 20.9 & 90.9 \\
Tertiary & 10 & 8.3 & 9.1 & 100.0 \\
Total & 110 & 89.8 & 100.0 & \\
No response & 10 & 10.2 & & \\
Total & 120 & 100.0 & & \\
\hline
\end{tabular}

Source: Field work, 2019

Table 4 below (see appendix 1) presents a frequency tabulation of the work experience of owners/managers of the SMEs. As can be observed from the table, a majority have low to medium number of years of experience in management. A total of $(\mathrm{N}=38)$ or $32 \%$ have low level of experience, while $(\mathrm{N}=49)$ or $45 \%$ have medium level of experience. On the other hand, a total of $(\mathrm{N}=14)$ or $12 \%$ and $(\mathrm{N}=9)$ or $8 \%$ have high and very high levels of experience respectively. The level of education is a vital determinant to business performance (Amarteifio, 2014). Unfortunately, in this study a majority of SME managers/owners have low or medium level business experience. This has implications on their management capabilities or their ability to plan appropriately for any changes in the business environment (Hisrich \& Drnovsek, 2002). 


\section{Macrothink}

Table 4. SME managers' years of experience

\begin{tabular}{lllll}
\hline & Frequency & Percent & Valid Percent & Cumulative Percent \\
\hline Low & 38 & 31.6 & 34.5 & 34.5 \\
Medium & 49 & 40.8 & 44.6 & 79.1 \\
High & 14 & 11.6 & 12.7 & 91.8 \\
very high & 9 & 7.5 & 8.2 & 100 \\
Total & 110 & 91.6 & 100 & \\
No response & 10 & 8.4 & & \\
Total & 120 & 100.0 & & \\
\hline
\end{tabular}

Source: Field work, 2019

\subsection{Financial Management Practices of SMEs}

Table 5 (see appendix 1) presents descriptive statistics of SME financial management practices. The highest mean $(\mathrm{M}=3.19)$ shows that most managers/owners follow expenditure guidelines. They also compare prices when shopping $(\mathrm{M}=3.06)$ for raw materials or making other capital expenditures. The table further shows that the age of SMEs in the study ranged from one (1) year to ten (10) years. Also, the standard of deviation for the variable age of business is 2.79 which implies that majority of the SMEs are within the five (5) to six (6) year bracket.

Table 5. Descriptive statistics on financial management practices

\begin{tabular}{llllll}
\hline & $\mathrm{N}$ & Min & Max & Mean & Std. Dev \\
\hline Age of the business & 110 & 1 & 10 & 3.07 & 2.79 \\
Expenditure guidelines & 110 & 1 & 5 & 3.19 & .81 \\
Have audited financial statements & 110 & 1 & 5 & 1.67 & .76 \\
Entrepreneur experience & 110 & 1 & 5 & 2.62 & .81 \\
Ability to interpret financial information & 110 & 1 & 5 & 2.07 & .91 \\
Seeks investment services & 110 & 1 & 5 & 1.48 & .50 \\
Seeks financial management services & 110 & 1 & 5 & 1.65 & .47 \\
Access to financial information & 110 & 1 & 5 & 2.36 & .95 \\
Financial responsibility & 110 & 1 & 5 & 2.58 & .90 \\
Compare prices when shopping & 110 & 1 & 5 & 3.06 & .94 \\
Prepares Budgets & 110 & 1 & 5 & 2.75 & .94 \\
Keeps track of expenditure and income & 110 & 1 & 5 & 2.61 & .92 \\
Maintains adequate financial record & 110 & 1 & 5 & 2.20 & .85 \\
Valid N (listwise) & 0 & & & & \\
\hline
\end{tabular}

Source: Field work, 2019

\subsubsection{Multiple Regressions}

A model summary of the regression analysis of the SME financial management practices and business growth is depicted in Table 6 below (see appendix 1). As can be observed from the table, $24.3 \%$ of the variability in business growth is explained by these financial management 
practices (budgeting, tracking of expenditure, educational background, enterpreneur experience, have audited financial statements, and level of financial responsibility). As such, $75.7 \%$ is unexplained by this model. Also the standard error of the regression was found to be 0.028 . This invariably suggests the explanatory variables are significantly associated with the dependent variable (business growth).

Table 6. Model summary

\begin{tabular}{lllll}
\hline Model & $\mathrm{R}$ & $\mathrm{R}$ Square & Adjusted R Square & Std. Error of the Estimate \\
\hline 1 & $.585^{\mathrm{a}}$ & .243 & .321 & 0.028 \\
\hline
\end{tabular}

a. Predictors: (Constant), Track of expenditure, Budgeting, Educational background, Audited financial statement, Entrepreneur experience, Financial responsibility

Source: Field work, 2019

An analysis of variance (ANOVA) of SME financial management practices and business growth is depicted in Table 7 below. The F value of $(15.544: p=0.001)$ is less than .05 , so it can be concluded that there is a statistically significant relationship between business growth and financial management practices.

Table 7. ANOVA ${ }^{\mathrm{a}}$

\begin{tabular}{llllll}
\hline Model & Sum of Squares & Df & Mean Square & F & Sig. \\
Regression & 247.290 & 6 & 41.215 & 15.544 & $.001^{\mathrm{b}}$ \\
1 Residual & 474.624 & 179 & 2.652 & & \\
Total & 721.914 & 185 & & & \\
\hline
\end{tabular}

a. Dependent Variable: Age of the business

b. Predictors (Constant): Track of expenditure, Budgeting, Educational background, Audited financial statement, Entrepreneur experience, Financial responsibility.

Source: Field work, 2019

Table 8 presents the Coefficients of the variables. As can be observed from the table, having audited financial statements $(p=0.001, \beta=0.621)$, educational background $(p=0.011, \beta=$ $0.319)$, and entrepreneur experience $(\mathrm{p}=0.000, \beta=0.818)$ had a statistically significant relationship with enterprise growth $(p<.05)$ and track of expenditure $(p=0.024, \beta=0.364)$. On the other hand, budgeting and financial responsibility were not statistically significant.

Table 8. Coefficients ${ }^{\mathrm{a}}$

\begin{tabular}{lllll}
\hline Model & $\begin{array}{l}\text { Unstandardized } \\
\text { Coefficients }\end{array}$ & $\begin{array}{l}\text { Standardized } \\
\text { Coefficients }\end{array}$ & t & Sig.
\end{tabular}




\begin{tabular}{lllll}
\hline & B & Std. Error & Beta & \\
\hline (Constant) & -1.816 & .733 & & -2.476 .014 \\
Audited financial & .621 & .182 & .209 & 3.414 .001 \\
statement & & .123 & .157 & 2.586 .011 \\
Educational background & .319 & .108 & .486 & 7.585 .000 \\
Entrepreneur experience & .819 & -.061 & -.947 .345 \\
Budgeting & -.138 & .146 & -.024 & -.355 .723 \\
Financial responsibility & -.048 & .134 & .139 & 2.273 .024 \\
Track of expenditure & .364 & .160 & & \\
\hline a. Dependent Variable: Age of the enterprise
\end{tabular}

Source: Field work, 2019

\section{Discussion of Results}

SME owner/manager educational status, managerial experience, and financial management practices can predict business growth (Mensah et al., 2015; Mbroh \& Attom, 2011). Higher education is expected to increase owners'/managers' ability to manage and grow SMEs (Amarteifio \& Agbeblewu, 2017). A study in Kenya by Kamunge, Njeru and Tirimba (2014) established that availability of managerial skills and experience affects businesses to a great extent. A study by Yusuf and Saffu (2005) did not find a significant relationship between education and the performance of Ghanaian SME owners/managers. In contrast with other professions such as medicine, accounting, law and engineering, Yusuf and Saffu (2005) posit that higher education is not a necessary requirement or a common characteristic of owners/managers in the SME sector. In this study however, higher educational background of SMEs had statistically significant relationship with enterprise growth.

Also, prior studies conducted in different countries have found that SME owners/managers with more managerial, or industry experience tend to have the ability to grow their enterprises (Agyei-Mensah, 2011; Anokye, 2017; Ansong \& Gyensare, 2012; Ekpo et al.,2017; Nunoo \& Andoh, 2012; Rajaram \& O'Neill 2009). In this study also, enterpreneur experience had a statistically significant relationship with enterprise growth. Similarly, a study in Ghana by Appiah, Aidoo and Kodjiku, (2019) using principal component analysis, it was that a unit increase in entrepreneur experience will lead to an increase in growth in terms of revenue and market shares by 0.219 and 0.241 respectively.

A number of studies have also examined the relationship between the financial management practices of SMEs and performance (Adomako \& Danso, 2014; Ansong \& Gyensare, 2012; Anokye, 2017). In Ghana for example, Nketsiah (2018) found a positive association between financial management practices and SMEs performance. According to the author, the effects of the financial management practices on SMEs performance depend on the longevity of the firm. Similarly, the results of this study revealed that financial management practices improve the performance and growth of SMEs in Ghana. The results reveal that when SME financial management practices are adopted and practiced, the SME will experience improvement and growth. 


\section{Macrothink Mnstitute ${ }^{\text {m" }}$}

\section{Conclusion and Recommendations}

The aim of the study was to examine how financial management skills are relevant for the success of SMEs. The financial capability of SME managers or owners can affect behavior in managing business finances (O'Donnell \& Keeney, 2010). Standard financial management practices can give SMEs an accurate depiction of business finances including revenues, expenses, profits, capital, cash flow and formal records that provide in-depth insights into financial information (International Finance Corporation, 2017).

The results of the study indicate the need for SMEs to improve on their financial management practices to improve the growth of their enterprises. Based on the findings, it is recommended that in order to survive, SMEs should first acquire financial management skills that assist in short-term decision making. Targeted financial education programmes by actors in the industry and entrepreneurship educators can help SMEs to develop a strategic approach to business financing and best financial management practices. This can include the relevance of bookkeeping, financial reporting and analysis as well maintaining proper books of analysis. Capacity building should be organized for SMEs owners to help them understand why they should keep updated books so as to know their levels of performance on whether they are making profits or losses.

Although we found a correlation or mutual relationship between the dependent variable (business growth) and the independent variables in our regression model, it doesn't necessarily mean that one causes the other. Further studies using longitudinal designs involving the observations of the same SMEs can provide a better basis for inferences about causality (i.e., Kline, 2011). Also, the study did not cover the challenges hindering SMEs from accessing financing from credit institutions. Future research in this area may establish the challenges and possible solutions for credit financing of SMEs. This can shed some light on whether accessing micro credit helps SMEs' performance.

\section{References}

Abbasi, W. A., Wang, Z., \& Abbasi, D. A. (2017). Potential sources of financing for small and medium enterprises (SMEs) and role of Government in supporting SMEs. Journal of Small Business and Entrepreneurship Development, 5(2), 39-47.

Abor, J. (2007). Corporate governance and financing decisions of Ghanaian listed firms: Corporate governance. The International Journal of Business in Society, 7(1), 83-92. https://doi.org/10.1108/14720700710727131

Abor, J., \& Biekpe, N. (2007). Small business reliance on bank financing in Ghana. Emerging Markets Finance \& Trade, 43(4), 93-102. https://doi.org/10.2753/REE1540-496X430405

Abor, J., \& Quartery, P. (2010). Issues in SME development in Ghana and South Africa. International Research Journal of Finance and Economics, 39, 218-28.

Abraham, F., \& Schmukler, S. (2017). Addressing the SME finance problem. Research and Policy Brief, 9. World Bank Malaysia Hub, World Bank, Washington, DC.

Ackah, J., \& Vuvor, S. (2011). The Challenges faced by Small and Medium Enterprises (SMEs) 
in obtaining credit in Ghana. School of Management, BTH University.

Adeniran, T. V., \& Johnston, K. A. (2012). Investigating the dynamic capabilities and competitive advantage of South African SMEs. African Journal of Business Management, 6(11), 4088-4099. https://doi.org/10.5897/AJBM11.1673

Adomako, S., \& Danso, A. (2014). Financial literacy and firm performance: The moderating role of financial capital availability and resource flexibility. International Journal of Management and Organizational Studies, 3(4), 1-15.

Agyei, S. K. (2018). Culture, financial literacy, and SME performance in Ghana. Cogent Economics \& Finance, 6, 1-16. https://doi.org/10.1080/23322039.2018.1463813

Agyei-Mensah, B. K. (2011). Financial management practices of small firms in Ghana: An empirical study. African Journal of Business Management, 5(10), 3781-3793. https://doi.org/10.2139/ssrn. 1597243

Akande, O. O. (2011). Accounting skill as a performance factor for small businesses in Nigeria. Journal of Emerging Trends in Economics and Management Sciences, 2(5), 372-378.

Alliance for Financial Inclusion (AFI). (2010). Financial inclusion measurement for regulators: Survey design and implementation. Policy Paper. (SMEF) Working Group.

Alliance for Financial Inclusion. (2019). SME finance guideline note. SME Finance (SMEF) Working Group, Guideline Note No.36... he.

Alvarez, C. A. (2011). Increasing access to credit through reforming secured transactions in the MENA Region. Policy Research Working, 5613.

Amarteifio, E. A., \& Agbeblewu, S. (2017). Level of education, business experience and small and medium enterprise performance in the Accra Metropolis of Ghana. International Journal of Multidisciplinary and Current Research, 5, 1-8.

Ankrah, E., Mensah, C. C. Y., \& Ofori-Atta, K. (2015). The Relevance of accounting information in the management of small scale businesses in the Yilo Krobo District in Ghana. European Journal of Business and Management, 7, 8.

Appiah, E., Aidoo, E., \& Kodjiku, S. L. (2019). Investigating factors that influence the growth of smes in Ghana: A case study of makorla market. European Journal of Business and Management, 11(3), 1-14.

Arcand, J., Berkes, E., \& Panizza, U. (2015). Too Much Finance? Journal of Economic Growth, 20, 105-48. https://doi.org/10.1007/s10887-015-9115-2

Aryeetey, E., \& Ahene, A. A. (2005). Changing Regulatory Environment for Small-Medium Size Industry and their Performance in Ghana. Centre on regulation and competition working paper series, Paper No.103/2005.

Association of Ghana Industries (AGI). (2001). Business Barometer report. Accra: Periodic opinion survey of chief executives of the business environment. 


\section{Macrothink

Ayyagari, M., Demirgüç-Kunt, A., \& Maksimovi, V. (2017). SME Finance. World Bank: Development Research Group, Policy Research Working Paper 8241. https://doi.org/10.1596/1813-9450-8241

Ayyagari, M., Juarros, P., Peria, M., \& Singh, S. (2016). Access to finance and job growth: Firm-level evidence across developing countries. World Bank Policy Research Working Paper 7604, Washington, DC. https://doi.org/10.1596/1813-9450-7604

Baker, M. (2001). Selecting a research methodology. The Marketing Review, 1, 373-397. Retrieved from http://www.themarketingreview.com

Balkenhol, B., \& Schütte, H. (2001). Collateral, collateral law and collateral substitutes (2nd ed.). Geneva: International Labour Office, Social Finance Programme, Working paper No. 26.

Beck, T. (2013). Bank financing for SMEs: Lessons from the Literature. National Institute Economic Review, 225(1), R23-R38. https://doi.org/10.1177/002795011322500105

Berisha, G., \& Pula, J. S. (2015). Defining small and medium enterprises: A critical review. Academic Journal of Business, Administration, Law and Social Sciences, 1(1). Retrieved from http://www.iipccl.org IIPCCL Publishing, Tirana-Albania.

Blancher, N. (2019). Financial inclusion of small and medium-sized enterprises in the Middle East and Central Asia. Washington, DC: International Monetary Fund, Publication Services. https://doi.org/10.5089/9781484383124.087

Blazy, R., \& Weill, L. (2013). Why do banks ask for collateral in SME lending? Applied Financial Economics, 23. https://doi.org/10.1080/09603107.2013.795272

Churchill, Q. R. (2013). Contemporary Approaches for Financing Micro, Small and Medium Enterprises. Conference on SME held at the International Conference Centre, Abuja, Nigeria, 2-15.

Cohen, L., Manion, L., \& Morrison, K. (2007). Research methods in education (6th ed.). London and New York: Routledge. https://doi.org/10.4324/9780203029053

Demirguc-Kunt, A., Beck, T., \& Honohan, P. (2008). Finance for all: Policies and pitfalls in expanding access. World Bank, Washington, DC.

Derbile, E. K., Abubakari, A., \& Dinye, R. D. (2012). Diagnosing challenges of small-scale industries Ghana: A case of agro-processing industries in Kassena-Nankana District. African Journal of Business Management, 6(47), 11648-11657.

Ekpo, N. B., Etukafia, N. I., Acha, I. A., Udoidem, J. O., \& Asogwa, I. E. (2017). Growth implications of managerial finance in business: Empirical evidence from Akwa Ibom State, Nigeria. World Journal of Economic and Finance, 3(1), 061-068.

European Commission. (2005). The new SME definition: user guide and model declaration section. Brussels: Office for Official Publications of the European Communities.

Faye, I., \& Thouraya, T. (2013). Financial inclusion in Africa: The transformative role of 
technology. Tunisia, African Development Bank (AfDB).

Finlayson, A. (2009). Financialisation, financial literacy and asset-based welfare. British Journal of Politics and International Relations, 11(3), 400-421. https://doi.org/10.1111/j.1467-856X.2009.00378.x

Gebregizabher, G. F., \& Akeem, A. O. (2015). An assessment of the roles of Small and Medium Enterprises (SMEs) in the local economic development (LED) in South Africa. Journal of Economics, 6(3), 280-290. https://doi.org/10.1080/09765239.2015.11917617

Ghana Statistical Service (GSS) GSS. (2014). Ghana living standards survey round 6 (GLSS 6): Poverty profile in Ghana, 2005-2013. Accra: Ghana Statistical Service.

Gitman, L. (2010). Principles of managerial finance (12th ed.). New York: Pearson.

Hishigsuren, G., Spahr, M., Estevez, I., \& Magnoni, B. (2014). Experiences of microfinance institutions serving very small-to-small enterprises in Latin America. Enterprise Development and Microfinance, 25, 246-258. https://doi.org/10.3362/17551986.2014.023

Hisrich, R. D., \& Drnovsek, M. (2002). Entrepreneurship and Small Business Research. Journal of Small Business and Enterprise Development, 9(2),172-222. https://doi.org/10.1108/14626000210427348

International Finance Corporation. (2017). MSME finance gap. Assessment of the shortfalls and opportunities in financing micro, small and medium enterprises in emerging markets. Washington, D.C: World Bank Group, Pennsylvania Avenue, N.W. https://doi.org/10.1596/28881

International Labour Office (ILO). (2007). The promotion of sustainable enterprises. Geneva International Labour Conference, 96th Session, Report VI, ISBN 978-92-2-118143-9.

International Labour Organization. (2007). The promotion of sustainable enterprises. Geneva: International Labour Conference 96th Session, Report VI.

International Monetary Fund. (2019). Financial inclusion of small and medium-sized enterprises in the Middle East and Central Asia. Washington, DC. IMF Publication Services.

International Trade Centre (ITC). (2016). SME competitiveness in Ghana: Alliances for Action. Geneva: ITC, No. OCE-16-27.E. https://doi.org/10.18356/b950ae91-en

Jankowicz, A. D. (2000). Business research projects (2nd ed.). Cleveland UK: Thomson Business Press ITP.

Kamunge1, M. S., Njeru, A., \& Tirimba, O. I. (2014). Factors affecting the performance of small and micro enterprises in limuru town market of kiambu county, Kenya. International Journal of Scientific and Research Publications, 4(12),1-20.

Kauffmann, C. (2006). Financing SMEs in Africa. Paris: OECD Development Centre, Policy Insight $\mathrm{nr} 7$. 


\section{Macrothink $\Lambda$ Institutem}

Kayanula, D., \& Quartey, P. (2000). The Policy Environment for Promoting Small and Medium-sized Enterprises in Ghana and Malawi. Finance and Development Research Programme Working Paper Series Paper No. 15.

Kirsten, C. L. (2013). The impact of training courses on financial management skills of South African small-business owners. International Business \& Economics Research Journal, 12(7), 1-10. https://doi.org/10.19030/iber.v12i7.7971

Kline, R. B. (2011). Principles and practice of structural equation modeling (3rd ed.). New London: Guilford Press.

Lee-Ross, D., \& Lashley, C. (2009). Entrepreneurship and small Business management in the hospitality industry. Oxford, UK: Elsevier's Science \& Technology. https://doi.org/10.1016/B978-0-7506-8448-4.00003-2

Longenecker, J. G., \& Loeza, E. L. (2010). Small Business Management (14th ed.). Cengage Learning.

Longenecker, J. G., Moore, C. W., Petty, J. W., \& Palich, L. E. (2008). Small Business Management: Launching and Growing Entrepreneurial Ventures (14th ed.). Thomson South-Western.

Maksimov, V., Wang, S. L., \& Luo, Y. (2017). Reducing poverty in the least developed countries: The role of small and medium enterprises. J. World Bus, 52, 244-257. https://doi.org/10.1016/j.jwb.2016.12.007

Mbroh, J. K., \& Attom, E. B. (2011). Accounting and Control Systems Practiced By Small and Micro Enterprise Owners within the Cape Coast Metropolitan Area of Ghana. Asian Journal of Business and Management Sciences, 1(9), 28-47.

McMahon, R. G. P., Holmes, S., Hutchinson, P. J., \& Forsaith, D. M. (2008). Small Enterprise Financial Management: Theory and Practice. Harcourt Brace, Sydney.

Mensah, H., Azinga, S., \& Sodji, J. (2015). Challenges faced by SMEs in accessing credit facilities from financial Institutions: An Empirical assessment incorporating the perception of both borrowers and financiers. International Journal of Economics, Commerce and Management, 3(11), 250-275.

Mensah, S. (2004). A review of SME financing schemes in Ghana. A paper presented at the UNIDO Regional Workshop of Financing Small and Medium Scale Enterprises, Accra, Ghana, 15-16 March.

Musah, A., Gakpetor, E. D., \& Pomaa, P. (2018). Financial management practices, firm growth and profitability of small and medium scale enterprises (SMEs). Information Management and Business Review, 10(3), 25-37. https://doi.org/10.22610/imbr.v10i3.2461

Nangoli, S., Turinawe, D. D., Kituyi, G. M., Kusemererwa, C., \& Jaaza, M. (2013). Towards enhancing business survival and growth rates in LDCs: An exploratory study of the drivers of business failure among SMMES in Kampala-Uganda. International Journal of Humanities and Social Science, 3(8), 284-291. 


\section{Macrothink

Nketsiah, I. (2015). Financial management practices and performance of small and medium enterprises in the Sekondi-Takoradi metropolis (Doctoral dissertation, University of Cape Coast).

Nketsiah, I. (2018). Financial management practices and performance of smes in Ghana: The moderating role of firm age. Open Journal of Economics and Commerce, 1(4), 8-18.

Nkuah, J. K. (2013). Financing small and medium nterprises (Smes). In Ghana: Challenges and Determinants in Accessing Bank Credit.

Nkuah, J. K., Tanyeh, J. P., \& Gaeten, K. (2013). Financing small and medium enterprises (Smes) in Ghana: Challenges and determinants in accessing bank credit. International Journal of Research in Social Sciences, 2(3), 1-14.

O’Donnell, N., \& Keeney, M. (2010). Financial capability in Ireland and a comparison with theUK. Public Money and Management, 30(6), 355-362. https://doi.org/10.1080/09540962.2010.525004

OECD. (1997). Small businesses, job creation and growth: Facts, obstacles and best practices. Retrieved from https://www.oecd.org/cfe/smes/2090740.pdf

OECD. (2005). OECD SME and Entrepreneurship Outlook: 2005, OECD Paris, page 17.

OECD. (2015). New approaches to SME and entrepreneurship financing: Broadening the range of instruments. OECD Centre for Entrepreneurship, SMEs and Local Development, Finance Ministers and Central Bank Governors at their meeting in Istanbul, 9-10 February. https://doi.org/10.1787/9789264240957-en

OECD. (2017). Enhancing the contributions of SMEs in a global and digitalised economy. Paris: Meeting of the OECD Council at Ministerial Level, 7-8 June.

OECD. (2018). Enhancing SME access to diversified financing instruments. Discussing Paper. OECD Ministerial Conference on Small and Medium-sized Enterprises, 22-23 February, Mexico.

Orford, J., Herrington, M., \& Wood, E. (2004). Global entrepreneurship monitor: 2004 South African report. The Centre for Innovation and Entrepreneurship, UCT Graduate School of Business, Cape Town.

Parker, S. C. (2003). What is entrepreneurship? A proposal for a data-based methodology. Academy of Entrepreneurship Journal, 9, 1-2.

Prempeh, K. B. (2015). Problems of financing SMES in Ghana: A case study of the Sunyani Municipality. Journal of The International Association of Advanced Technology and Science, 16, 1-39.

Quartey, P., Turkson, E., Abor, J. Y., \& Iddrisu, A. M. (2017). Financing the growth of SMEs in Africa: What are the contraints to SMEfinancing within ECOWAS. Review of Development Finance, 7, 18-28. https://doi.org/10.1016/j.rdf.2017.03.001

Rajaram, R., \& O`Neill, C. (2009). Profit or no profit: Does the SME sector really know? 
Alternation, 16(1), 99-119.

Ross, S. A., Westerfield, R. W., \& Jaffe, J. (2009). Corporate Finance (5th ed.). Irwin and McRaw-Hill, Boston.

Shinozaki, S. (2012). A New Regime of SME Finance in Emerging Asia: Empowering GrowthOriented SMEs to Build Resilient National Economies. ADB Working Paper Series on Regional Economic Integration, No. 104, Asian Development Bank (ADB), Manila.

Shinozaki, S. (2012). A New regime of SME finance in emerging Asia: Empowering growthoriented SMEs to build resilient national economies. ADB Working Paper Series on Regional Economic Integration, No. 104, Asian Development Bank (ADB), Manila.

Singh, N. (2003). Building social capital through micro-finance: A perspective on the growth of micro-finance sector with special reference to India. IFAD literature on Micro Finance.

Todaro, M. P. (1989). Economic Development in the Third World. New York.

United Nations. (2001). Improving the competitiveness of SMEs in developing countries: The role of finance to enhance enterprise development. New York and Geneva, UNCTAD's intergovernmental Expert Meeting, 22-24 October.

World Bank (2016). Access to finance for small and medium enterprises in Africa. Accra, Ghana.

World Bank Group. (2018). Improving Access to finance for SMEs through: Opportunities through credit reporting, secured lending, insolvency practices.

Yusuf, A., \& Saffu, K. (2005). Planning and performance of small and medium sized enterprises operators in a country in transition. Journal of Small Business Management, 43(4), 480-497. https://doi.org/10.1111/j.1540-627X.2005.00148.x

\section{Copyright Disclaimer}

Copyright reserved by the author(s).

This article is an open-access article distributed under the terms and conditions of the Creative Commons Attribution license (http://creativecommons.org/licenses/by/3.0/). 